\title{
Assessment of corn starch as substitute for agarose in DNA gel electrophoresis
}

\author{
Francis Tanam Djankpa ${ }^{* *}$ (D), Gideon Akuamoah Wiafe ${ }^{2}$, Bernard Ntim Boateng ${ }^{3}$, Korantema Mawuena Tsegah², \\ Samuel Essien-Baidoo ${ }^{3}$, Mark Bilinyi Ulanja ${ }^{4}$, Kwame Ofori Affram ${ }^{5}$, Abdala Mumuni Ussif ${ }^{6}$, \\ Desmond Owusu Agyeman ${ }^{1}$ and Gabriel Asante ${ }^{1}$
}

\begin{abstract}
Objective: The use of agarose in nucleic acid electrophoresis is the gold standard. However, agarose is very expensive and not readily available in resource limited developing countries like Ghana. Hence, finding a more affordable and readily available alternative to agarose will be a major boost to molecular research in developing countries. This study was aimed at investigating the use of corn starch as a potential substitute for agarose in DNA gel electrophoresis.

Results: Genomic deoxyribonucleic acid (DNA) extracted from Plasmodium falciparum and primers were obtained from the West African Centre for Cell Biology of Infectious Pathogens and amplified using polymerase chain reaction. The amplicon was run on agarose gel to ascertain the molecular weight (as a positive control). When visualized under both blue light and ultraviolet light, the DNA and ladder showed clear and clean bands with the expected molecular weight. Corn starch was then modified with sodium borate buffer, casted into a gel and used to run the same DNA sample. Our findings indicated that similar to agarose, the DNA sample and ladder migrated successfully through the modified starch gel but no bands were visible when visualized under blue and ultra-violet light.
\end{abstract}

Keywords: Electrophoresis, Gel, DNA, Corn, Starch, Agarose

\section{Introduction}

One of the most important techniques employed in molecular biology is gel electrophoresis, the separation of charged molecules such as nucleic acids and proteins in a stationary colloidal medium by passing an electric current through it [1]. The popularity and standard use of agarose gels as electrophoretic medium stems from many advantages that agarose offers. Chiefly, that gels are easy to cast [2], are suitable for separating large and moderately-sized DNA molecules [3], have wide separation range [4] and provide a nontoxic gel medium [3]. However, agarose gels produce poor band resolution and

\footnotetext{
*Correspondence: fdjankpa@ucc.edu.gh

${ }^{1}$ Department of Physiology, School of Medical Sciences, College

of Health and AlliedSciences, University of Cape Coast, Cape Coast, Ghana

Full list of author information is available at the end of the article
}

are unsuitable for samples of low molecular weight [3]. These disadvantages may be remedied using polyacrylamide gels. Polyacrylamide gels also have disadvantages. Acrylamide, from which the gel is prepared, is toxic and the gels are fragile, difficult to handle and tedious to work with [3]. The cost of both agarose and acrylamide is disapprovingly high and constitute a hindrance to molecular studies in resource-poor laboratories of developing countries. An exploration of other suitable electrophoretic media is therefore needed to address this challenge.

Prior to the emergence of agarose as the dominant electrophoretic medium in the mid-to-late 1960s, materials such as starch and agar were also in popular use [5]. Starch as an electrophoretic medium has sadly fallen out of popular use in modern science. Importantly, starch is abundant and inexpensive in sub-Saharan Africa, which 
could be great assets for the scientific community in that region.

We therefore assessed the usefulness of corn starch as a substitute for agarose in DNA gel electrophoresis.

\section{Main text \\ Methods \\ Amplification of histidine rich protein-II (Hrp-II) of Plasmodium falciparum}

The genomic DNA was amplified through polymerase chain reaction (PCR). The DNA amplicon was run on agarose gel to ascertain the molecular weight. Thereafter, the amplicon was also run on modified corn starch gel for comparison.

The PCR was run using the New England Biolab (NEB) PCR master mix. The PCR reaction mixture was set to a total volume of $25 \mu \mathrm{l}$. The tubes were transferred into the thermal cycler (GeneAmp ${ }^{\circledR}$ PCR System 9700), set according to NEB guidelines. Briefly, an initial denaturation process at $94{ }^{\circ} \mathrm{C}$ for $30 \mathrm{~s}$, a 30 -cycle process involving three different temperatures and time readings $\left(94^{\circ} \mathrm{C}\right.$ for $30 \mathrm{~s}, 55^{\circ} \mathrm{C}$ for $30 \mathrm{~s}$ and $68{ }^{\circ} \mathrm{C}$ for $50 \mathrm{~s}$ ), a final extension process at $68{ }^{\circ} \mathrm{C}$ for $5 \mathrm{~min}$ and a hold at $4{ }^{\circ} \mathrm{C}$ after the process was complete.

\section{Preparation of 1 L of 1X TAE buffer from 50X stock}

A volume of $20 \mathrm{ml}$ of 50X TAE (tris-acetate EDTA (Ethylenediaminetetraacetic Acid)) was measured into a $1 \mathrm{~L}$ beaker. It was topped up with $980 \mathrm{ml}$ of distilled water up to the $1 \mathrm{~L}$ mark to obtain a working solution of $1 \times$.

\section{Preparation of $0.9 \%$ agarose gel}

An amount of $0.9 \mathrm{~g}$ of agarose powder was weighed and transferred into $100 \mathrm{ml}$ of the prepared TAE. It was stirred gently and microwaved for $60 \mathrm{~s}$ initially, and $20 \mathrm{~s}$ subsequently until the solution was clear. The solution was allowed to cool for $5 \mathrm{~min}$ and $30 \mu \mathrm{l}$ of DNA staining dye (Apex safe DNA gel stain) was pipetted into the agarose solution. The solution was stirred gently and poured into the gel cast. A fifteen (15) well comb was inserted and the gel was allowed to solidify. The comb was gently removed and the gel placed into a horizontal gel tank (Cleaver Scientific). The $1 \times$ TAE solution was poured into the gel tank to the maximum mark.

\section{Loading samples into agarose gel}

Twenty microliters $(20 \mu \mathrm{l})$ of $1 \mathrm{~kb}$ DNA ladder (NEB) was pipetted into the first (1st), ninth (9th) and twelfth (12th) wells. The Apex safe DNA loading dye (5X) was added to all samples to obtain a final concentration of $1 \mathrm{X}$. Twelve microliters $(12 \mu \mathrm{l})$ of the DNA and dye mixture was loaded into the fourth (4th) and seventh (7th) wells and electrophoresis was run at $80 \mathrm{~V}$ and 300 Watts for $2 \mathrm{~h}$. The gel was removed and viewed for band formation using a blue light box (Accuris Instruments ${ }^{\mathrm{TM}}$ $\left.\operatorname{Smartdoc}^{\mathrm{TM}}\right)$.

\section{Corn starch gel preparation}

The industrial corn starch was modified and used to prepare the gel. A literature search found no clear protocol to suit our purpose. We therefore modified and adjusted protocols previously described [6]. Hence, we used a novel protocol for making starch gel by modifying previous ones. Thirty-six grams (36 g) of the corn starch was weighed. Boric acid and sodium hydroxide buffer were prepared by weighing $1.855 \mathrm{~g}$ of boric acid into a $1 \mathrm{~L}$ beaker which contained $200 \mathrm{ml}$ of distilled water and $0.48 \mathrm{~g}$ of $\mathrm{NaOH}$ was added to the solution. The solution was topped up with distilled water to the $1 \mathrm{~L}$ mark. The weighed corn starch was poured into $200 \mathrm{ml}$ of prepared boric acid and $\mathrm{NaOH}$ buffer. It was stirred very well and allowed to stand in water bath for $30 \mathrm{~min}$ at $50{ }^{\circ} \mathrm{C}$. The supernatant was discarded and the sediment retained. Thirty (30) $\mathrm{ml}$ of distilled water was added to the sediment and mixed carefully. The sediment was allowed to settle and the supernatant, gently poured out. It was dried overnight at $70{ }^{\circ} \mathrm{C}$ in an incubator. After drying, the starch was ground into a smooth powder using a pestle and mortar. An amount of $12 \mathrm{~g}$ of the modified corn starch was weighed. Hundred (100) ml of TAE buffer was measured into a glass beaker and boiled on a hot plate with constant stirring. The modified starch was added to the boiling TAE buffer and stirred carefully for a homogenous mixture. The mixture was allowed to cool down for about 3 min and then thirty (30) $\mu$ l of Apex DNA gel stain was pipetted into the mixture and stirred to mix evenly. The cooled starch was poured into the horizontal gel cast tray with comb inserted and allowed to stand overnight at room temperature to dry gradually and attain a firm texture.

\section{Loading samples into corn starch gel}

Twenty microliters $(20 \mu \mathrm{l})$ of $1 \mathrm{~kb}$ DNA ladder (NEB) was pipetted into the first (1st), ninth (9th) and twelfth (12th) wells. We added 5X Apex safe DNA loading dye to all samples to obtain a final concentration of $1 \mathrm{X}$. Twelve microliters $(12 \mu \mathrm{l})$ of the DNA and dye mixture was loaded into the fourth (4th) and seventh (7th) wells and electrophoresis was run at $80 \mathrm{~V}$ and 300 Watts for $2 \mathrm{~h}$. The starch gel was removed and viewed for band formation using a blue light box (Accuris Instruments ${ }^{\mathrm{TM}}$ $\operatorname{Smartdoc}^{\mathrm{TM}}$ ).

\section{Results and discussion}

Starch is composed of two large $\alpha$-linked glucosecontaining polymers namely the smaller and linear 
(amylose), and the very large and highly branched (amylopectin) [7], whereas agarose consists of repeated residues of 1,3-linked $\beta$-D-galactopyranose and 1,4-linked 3,6-anhydro- $\alpha$-L-galactopyranose [8]. Agarose gel electrophoresis was done as a positive control to corn starch gel electrophoresis. The genomic DNA (Hrp-II gene), was found to have a molecular weight of 300-bp as expected (Fig. 1b). The starch gel was prepared over a 24-h period and yielded quiet satisfactory results for electrophoretic use. These observations revealed that corn starch under appropriate and carefully prepared conditions has the potential to be used for DNA gel electrophoresis especially in resource-limited countries. The starch gel prepared from the modified starch appeared a little cloudy and translucent initially with some opacity as it cooled down compared with that of agarose. The wells into which the samples were loaded were clearly formed providing some proof of the gelling properties of the corn starch (Fig. 2). The DNA samples were seen migrating clearly through the corn starch gel at different times throughout the electrophoresis i.e. after $10 \mathrm{~min}$ (Fig. 3b), $30 \mathrm{~min}$ (Fig. 3c) and $90 \mathrm{~min}$ (Fig. 3d). Branch chain lengths of amylopectin and their distributions play a major role in affecting the gelatinization temperature of starch. Without other structural differences, such as phosphate monoester contents, starch which contains longer branch chain lengths displays a higher gelatinization temperature and forms a stronger gel [9]. According to Meyer and colleagues [10], starch paste without added amylose would yield a highly viscous liquid and this was observed in our experiment hence the need for starch modification before gelling. The use of a higher concentration of starch without addition of amylose, on the other hand, may lead to the formation of a solid gel [10].

During our experiment, the migration of DNA samples and the ladder occurred through the corn starch gel as shown in Fig. 3 but no DNA bands were seen when visualized using the blue light box and ultra violet light box. The absence of DNA bands in the corn starch suggests two things; either the cross bridges between the DNA and the DNA staining dye were not formed due to the structure of the starch gel or formed but were not visible due to the level of opacity of the starch gel. Cross bridges are usually formed by a cross reaction between the DNA staining dye (Apex safe DNA gel stain) and the DNA molecules and these become visible under blue light or ultra violet light. This was possibly due to differences in reactivity between starch and the DNA staining dye. Secondly, the bands could have been formed but were invisible due to the level of opacity of the corn starch gel. A similar experiment was performed by Smithies [11] where he showed the group variations in the serum proteins of normal human adults using starch as a gel for zone electrophoresis. He found that most of the new components demonstrated by the starch gel method are derived from $\alpha 2$-globulin, which proves to be a complex mixture of many different proteins migrating in the starch gels ahead of $\beta$-globulin and some behind. Similarly, Bernfeld and colleagues [12] also conducted an experiment in which they showed the separation of protein by zone electrophoresis on a starch gel. The use of starch gel to separate proteins by these authors give a hope for future studies that DNA can be separated using starch gel. We therefore recommend that further work
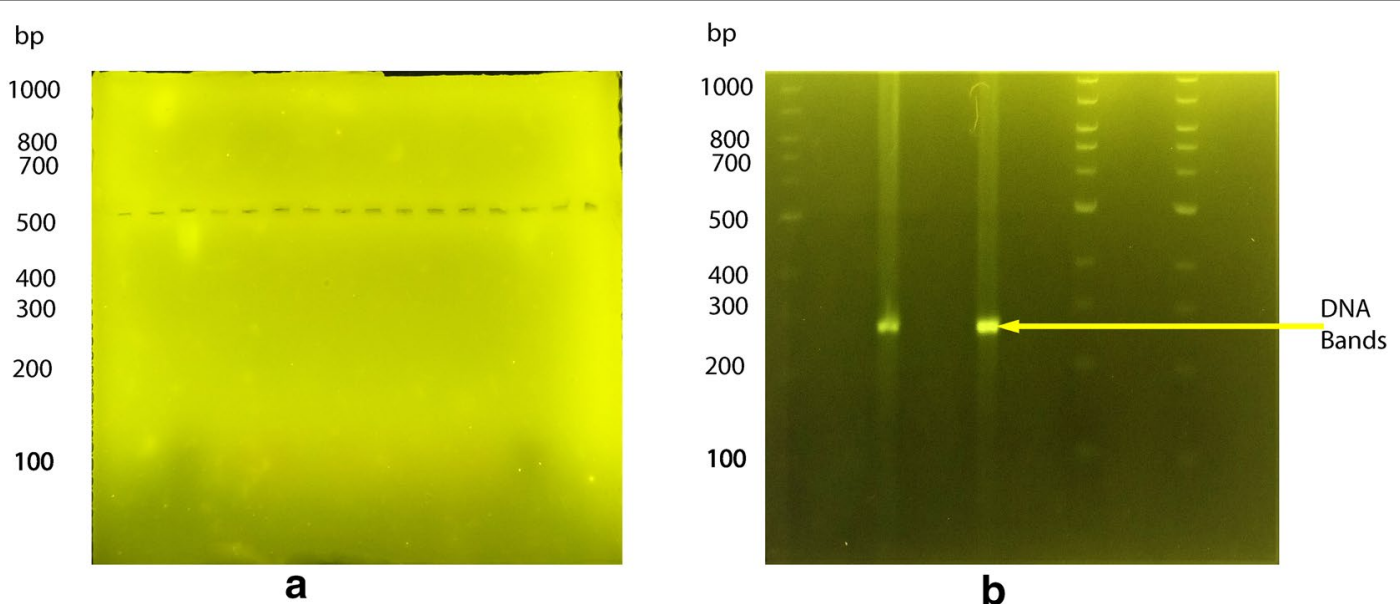

Fig. 1 Comparison of gels viewed under blue light. a Corn starch gel viewed under blue light with no bands seen. b Agarose gel viewed under blue light showing DNA bands. The first and the last 2 lanes show the $1 \mathrm{~kb}$ DNA ladder whereas the middle samples show the DNA bands around the expected molecular weight of about 300 base pairs 


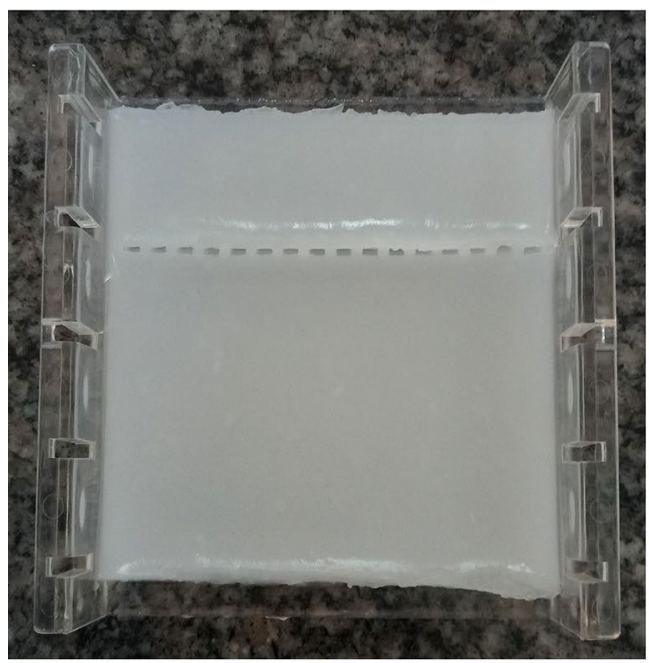

a

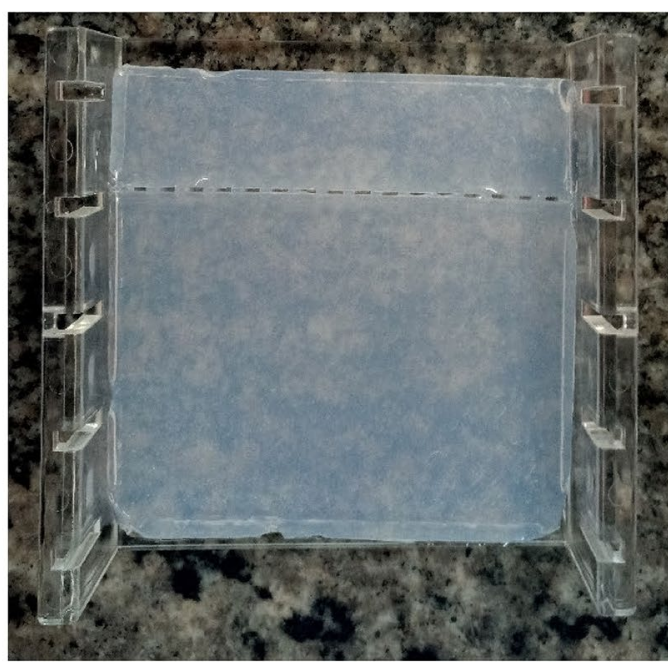

b

Fig. 2 Comparison of modified corn starch gel and agarose gel. Wells were clearly formed in both gels. a The corn starch gel appeared cloudy and translucent. It was fragile. $\mathbf{b}$ Agarose gel was transparent, firm and easy to handle

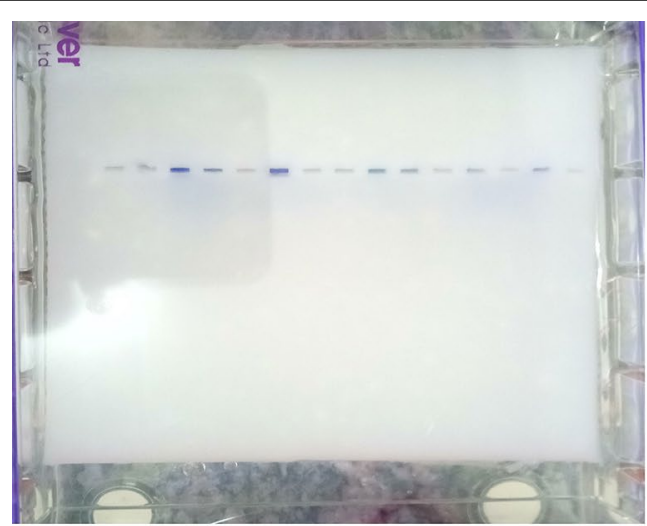

a

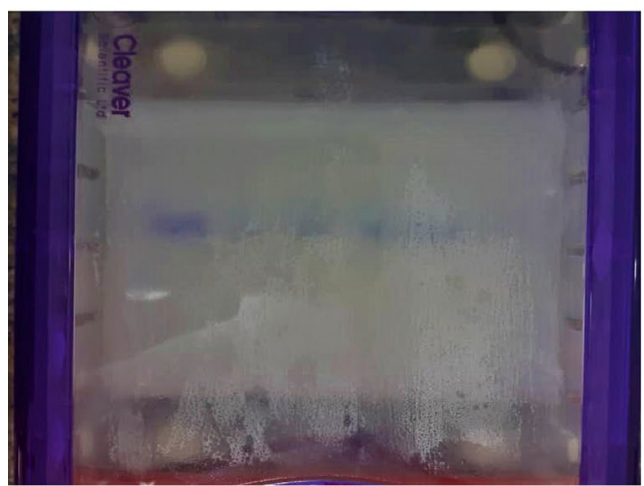

C

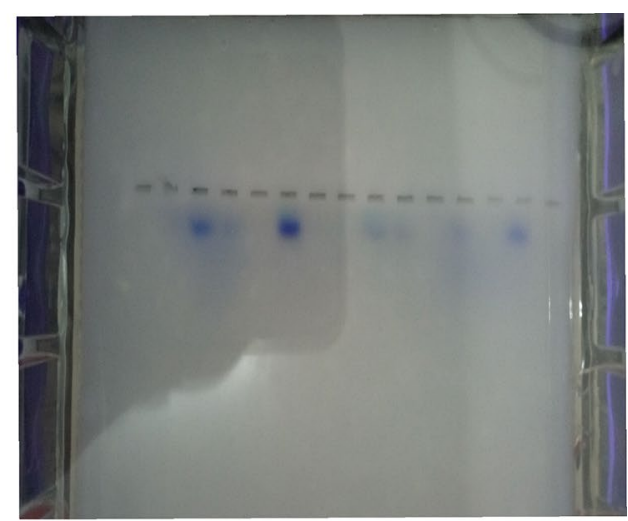

b

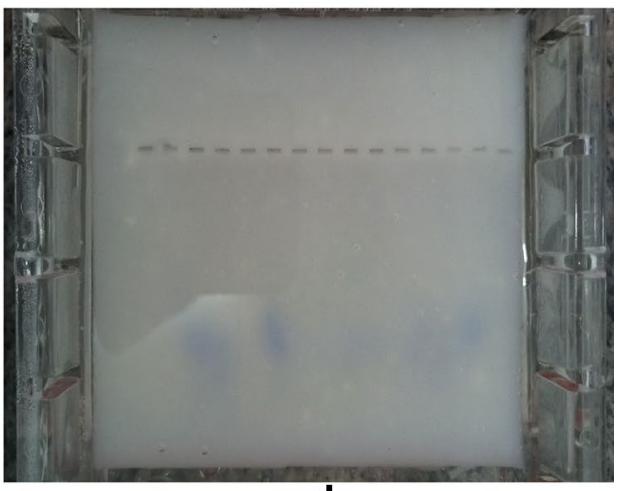

d

Fig. 3 Migration of loaded DNA ladder (DL) and DNA sample (DS) on corn starch gel. a Shows the loaded samples (DNA+ Apex Safe DNA loading dye), and the $1 \mathrm{~kb}$ DNA ladder (DL) on the starch gel at the onset. b Shows a migration of samples and DL 10 min after we started running the gel. c Shows migration of samples and DL at 30 min after we started running the gel. d Shows migration of samples and DL at 90 min after we started running the gel 
be done on the optimization of starch gel in DNA gel electrophoresis.

\section{Limitations}

We had few limitations in this research. The starch gel we prepared was optimized at $12 \%$ versus but we were compelled to use $0.9 \%$ for the agarose gel for comparison. Because of the large size of our cast and the nature of our protocols, we needed a higher quantity of starch to fill it up to ensure uniformity and equal thickness of our gel. Ideally, we should have match up the agarose to $12 \%$ but our DNA amplicon size was only suitable for low percentage gel of $0.9-2 \%$. Due to limitation in resources we got the DNA and primers as gift from another laboratory and run the PCR to get our amplicon which was suitable for a low molecular weight gel. The disparity in molecular weight between starch and agarose gel could have accounted for the absence of bands on the starch gel. Although our research does not show any positive results, we do not rule out the possibility of starch having the potential to replace agarose in DNA gel electrophoresis in resource limited areas. We advocate for further research and further optimization of our protocols to arrive at a definite conclusion. We are very pleased to announce here that our modified corn starch protocol has produced some positive results leading to the formation of a solid and stable starch gel which clearly allowed the migration of both DNA and the $1 \mathrm{~kb}$ ladder. Here we wish to resound a take home message that based on our preliminary findings we believe that corn starch has the potential to replace agarose. The DNA sample and ladder showed clear migration through the corn starch which is great sign of potential breakthrough in the near future. Our findings though preliminary are reproducible and can also be optimized when given more resources.

\section{Abbreviations \\ DNA: Deoxyribonucleic acid; Hrp-II: Histidine rich protein Il; PCR: Polymerase chain reaction; NEB: New England Biolabs; EDTA: Ethylenediaminetetraacetic Acid; TAE: Tris-Acetate EDTA; NaOH: Sodium hydroxide; DRIC: Directorate of research innovation and consultancy.}

\section{Acknowledgements \\ We thank Dr. Charles Hagan and Mr. Harry Danwonno of the West African Centre for Cell Biology of Infectious Pathogens (WACCBIP) for giving us the DNA and primers for this project. We thank Miss Josephine Esi Franklin Afful of the Department of Physiology, School of Medical Sciences for helping us with minor correction and typos. We also thank Mr. David Nuertey for helping with some aspect of PCR.}

\section{Authors' contribution}

FTD, MBU and KOA conceived the idea and developed it into research concept. They also contributed to the manuscript writing. FTD who is the corresponding author supervised the day to day running of PCR experiments. GAW and BNB are BSc Students who worked on this project as part of their BSC Thesis. They developed the research concept into a proposal, took active part in the laboratory work and contributed to manuscript writing as well. They were supervised by KMT and SEB who also contributed to the manuscript writing. DOA and GA were research assistants were worked extensively to optimize our modified starch protocol. They contributed in writing the methodology of the manuscript. AMU contributed to the manuscript writing. All authors read and approved the final manuscript.

\section{Funding}

This research was funded by the Directorate of Research Innovation and Consultancy (DRIC) of the University of Cape Coast. Grant Number RSG/IND/ CoHAS/2018.

\section{Availability of data and materials}

The data and material used during the current study are available from the corresponding author on reasonable request.

\section{Ethics approval and consent to participate}

Not applicable.

\section{Consent for publication}

Not applicable.

\section{Competing interests}

The authors declare that there is no conflict of interest of any kind in this study.

\section{Author details \\ 1 Department of Physiology, School of Medical Sciences, College of Health and AlliedSciences, University of Cape Coast, Cape Coast, Ghana. ${ }^{2}$ Depart- ment of Biomedical Sciences, School of Allied Health Sciences, College of Health and Allied Sciences, University of Cape Coast, Cape Coast, Ghana. ${ }^{3}$ Department of Medical Laboratory Sciences, School of Allied Health Sci- ences, College of Health and Allied Sciences, University of Cape Coast, Cape Coast, Ghana. ${ }^{4}$ Department of Internal Medicine, University of Nevada, Reno School of Medicine, 1155 Mill St, Reno, NV 89502, USA. ${ }^{5}$ Piedmont Athens Regional Medical Center, Graduate Medical Education, Athens, GA, USA. \\ ${ }^{6}$ Department of Forensic Sciences, School of Biological Sciences, University of Cape Coast, Cape Coast, Ghana.}

Received: 15 November 2020 Accepted: 10 February 2021

Published online: 25 February 2021

\section{References}

1. Rudge SR, Monnig CA. Electrophoresis techniques. Sep Purif Methods. 2000;29(1):129-48. https://doi.org/10.1081/SPM-100100006.

2. Chawla HS. Introduction to Plant Biotechnology (3/e). Boca Raton: CRC Press; 2011. https://doi.org/10.1201/9781315275369.

3. Barril P, Nates S. Introduction to agarose and polyacrylamide gel electrophoresis matrices with respect to their detection sensitivities. Gel Electrophor-Princ Basics. 2012. https://doi.org/10.5772/38573.

4. Stellwagen NC. DNA Gel Electrophoresis. In: Tietz D, editor. Nucleic Acid Electrophoresis. Springer: Springer Lab Manual; 1998. p. 1-53. https://doi. org/10.1007/978-3-642-58924-9_1.

5. Richards EG, Coll JA, Gratzer WB. Disc electrophoresis of ribonucleic acid in polyacrylamide gels. Anal Biochem. 1965;12(3):452-71. https://doi. org/10.1016/0003-2697(65)90212-5.

6. BeMiller JN. Corn Starch Modification. In: Serna-Saldivar SO, ed. Corn (Third Edition). AACC International Press; 2019:537-549. doi:https://doi. org/10.1016/B978-0-12-811971-6.00019-X

7. Hamaker BR, Tuncil YE, Shen X. Carbohydrates of the Kernel. In: Serna-Saldivar SO, ed. Corn (Third Edition). AACC International Press; 2019:305-318. doi:https://doi.org/10.1016/B978-0-12-811971-6.00011-5

8. Araki C. Structure of the Agarose Constituent of Agar-agar. Bull Chem Soc Jpn. 1956;29(4):543-4. https://doi.org/10.1246/bcsj.29.543.

9. Chen YY, Mcpherson AE, Radosavljevic M, Lee V, Wong KS, Jane J. Effects of starch chemical structures on gelatinization and pasting properties. Żywność Technol Jakość. 1998:17:63-71.

10. Meyer KH, Bernfeld P, Wolf E. Recherches sur l'amidon III. Fractionnement et purification de l'amylose de maïs naturel. Helv Chim Acta. 1940;23(1):854-64. 
11. Smithies O. An improved procedure for starch-gel electrophoresis: further variations in the serum proteins of normal individuals. Biochem $\mathrm{J}$. 1959;71(3):585-7.

12. Meyer KH, Bernfeld P, Wolf E. Research on starch III. Fractionation and purification of amyloidosis of natural corn. Helv Chim Acta. 1940;23(1):85464. https://doi.org/10.1002/hlca.194002301110.

\section{Publisher's Note}

Springer Nature remains neutral with regard to jurisdictional claims in published maps and institutional affiliations.
Ready to submit your research? Choose BMC and benefit from:

- fast, convenient online submission

- thorough peer review by experienced researchers in your field

- rapid publication on acceptance

- support for research data, including large and complex data types

- gold Open Access which fosters wider collaboration and increased citations

- maximum visibility for your research: over $100 \mathrm{M}$ website views per year

At BMC, research is always in progress.

Learn more biomedcentral.com/submissions 